\title{
Deformation of the Date Palm tree trunk in Dammam Metropolitan Area: causes and consequences
}

\begin{abstract}
Date palm (Phoenix dactylifera) is one of the elegant trees that performs several landscaping functions. Its single trunk textured by bases of the cut leaves distinguishes it from other ornamental trees. This cylindrical textured trunk is one of the major attractive features emphasized the use of date palms as ornamental landscaping trees. Across the Kingdom of Saudi Arabia, Date palms in public landscaping schemes have experienced deformation of their trunks. This is a function of several factors related to plantation, irrigation, and maintenance.
\end{abstract}

This research to investigate and categorise the causes, types, and forms of date palm trees' trunks deformation. Prior to a field survey, a randomly conducted pilot survey to collect data from different areas where date palms are used as landscaping ornamental trees across the Dammam Metropolitan Area (DMA). It applies direct observation, measuring and analysis to develop preliminary understanding of the phenomena; and apply its outcomes on a case study of the Dammam City Seafront (DCS). The result showed that date palm trees' trunks deformation has occurred at bottom, middle, and upper parts as results of several factors; and it is as high as almost $97 \%$ among investigated trees. However, 58\% of deformation symptoms processes have been noticed on bottom third of the date palm trees' trunks, near soil surface; and $27.5 \%$ of them are in the King Abdullah Seafront Park (KASP).

The study proves statistically that sprinkler and bubbler irrigation systems are of major responsibility for near ground deformation of palm trees' trunks, which expands at rate of 3.5 and $3.3 \mathrm{CM} /$ Year.
Ali Omar Al-Sulbi*

Imam Abdulrahman bin Faisal University, College of Architecture and Planning, Department of Landscape Architecture, Dammam , Kingdom of Saudi Arabia

*Corresponding author: Ali Omar Al-Sulbi, Imam Abdulrahman bin Faisal University, College of Architecture and Planning, department of Landscape Architecture, P O Box 2397 Dammam 31451, Kingdom of Saudi Arabia.Email: aalsulbi@iau.edu.sa

\section{Keywords:}

Date Palm (Phoenix dactylifera L.), Trunks deformation, Dammam

Metropolitan Area, Landscaping, ornamental tree 


\section{Introduction}

Date palm (Phoenix dactylifera) is the most important tree in the Kingdom of Saudi Arabia (KSA) and other tropical parts of the World. It is a source of food and wealth, used as national symbol representing the historic economy of the KSA. According to Food and Agriculture Organization (FAO), all parts of the date palms (except the roots) are used for a purpose best suited to them (FAO 2016).They produce dates; the cheapest food and sweet, their trunk and fronds used as building materials and site furniture, and as source of energy. Moreover, it is widely used as ornamental landscaping tree in the streets, parks and private home gardens. In 2009, the agricultural statistics showed that about 23.5 million palm trees were planted across the KSA (MOA 2009).

The date palm is a monocotyledon tall, slow growing tree, tolerate being in salty and alkaline soils and can grow in very hot and dry climates (Chao \& Krueger 2007). It is distinguished from other ornamental plants as an elegant, impressive tree with a single robust wide straighttrunk covered from ground level to the top with the overlapping persistent woody died leaves' bases (Simon 1978; Ricks 1992; Al-Shayeb et al. 1995; Al-Wehaibi 2008; Al-Kashman et al. 2011). In addition to its adaptability to harsh climatic and environmental conditions of the KSA, date palm adds aesthetic and visual landscape values to the sites where it is planted (Sayan 2001). The long pinnate leaves (also called fronds) resembling a large feather, originating from the growth point at the top of the palm tree trunk, creating the spherical or semispherical canopy form (Ricks 1992; Barreveld 1993). Date palms can produce number of off-shoots at different levels on their trunks, which copy the same characteristics of their mothers.

Roots of the date palms originate from the ballshaped foot of the palm tree trunk with no tap root and have little or no branching (Barreveld 1993).

The root system of the date palms is diveded into four zones (figure 1): (I) zone of the roots emerge from the upper part of the palm tree trunk base which do not go deeper than $25 \mathrm{~cm}$; (II) intensive rooting zone from $25-100 \mathrm{~cm}$ below the ground level; (III) zone of $100-200 \mathrm{~cm}$ below the ground level where the roots developed based on the availability of the nutrients in the upper zones; and finally (IV) zone of $200 \mathrm{~cm}$ below ground level where roots developed with strong geotropism searching for water (Barreveld 1993).

Adventitious roots are usually growing from the palm tree trunk near the base in the presence of appropriate conditions such as change of soil level and availability of moisture (Robinson \& Williams 2016).
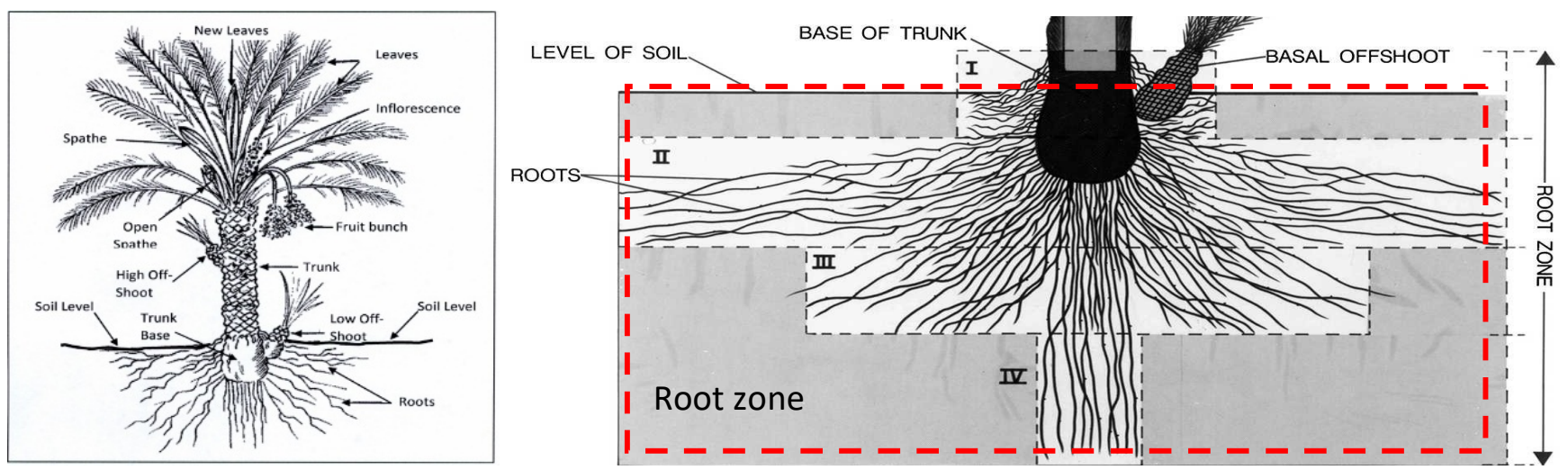

Figure 1: Major parts of the date palm tree (left): root zone, Trunk with off-shoots from the base or along the trunk, and the fronds (leaves). Rootzone divisions (right): zone I: shallow roots emerge from the trunk above the base, less than $25 \mathrm{~cm}$. below the soil level; zone II: intensive rooting up to $100 \mathrm{~cm}$ deep; zone III: $100-200 \mathrm{~cm}$ below surface level, developed based on nutrients availability on above zones; and zone IV: from $200 \mathrm{~cm}$ deep on a geotropism orientation searching for water. (Modified from FAO 2016; Barreveld 1993). 
Date palm has distinguished from other palms of the same Genus by the following characteristics:

- The ability of plant to produce off-shoots which produce plants of mothers' similar characteristics

- It is a tall, columnar plant with thick cylindrical trunk, reaches the height of more than 20 meters if the crown of fronds included (Ricks 1992 ;Zaid \& de Wet 2016). Its cylinderical columinar trunk of the same girth all the way up reaches an average circumferences of 1.00 -1.10 meters (Zaid \& de Wet, 2016).

- It has dark green leaves with variation in color shades according to varities

- Easy of hybirdization across pollination with other species: $P$. dactylifera with $P$. sylvestris in India; $P$. dactylifera with $P$. canariensis in North Africa and Palestine; $P$. dactylifera with $P$. reclinata in Senegal (Moore 1963).

Date palm tree is not like other trees in case of developing thick (wider) trunks as growing older. Date palm (Phoenix dactylifera) has developed its thick trunk at its earlier growing stage which continues growing vertically in slim cylindrical manner of same girth (Al-Baker 2002), unless deforms by one or more of the palm tree trunks' deformation causes.

Al-Mana and Ahmed (2010) have confirmed the cylindrical stem as the most important special character of the date palm tree emphasizes its use in street landscaping. The stem is covered with the leaf bases in spiral arrangements that give it a unique texture and visual picturesque, especially with light effects. Date palm tree trunk does not have a cambium layer; and it is composed of tough, fibrous vascular bundles cemented together in a matrix of cellular tissue which is much lignified near the outer part of the palm tree trunk (Figure 2). Lateral growth of the palm tree trunk is ensured by an extra fascicular cambium (results in a constant and uniform palm tree trunk width during the palm's entire life) and soon disappears (Zaid \& de Wet 2016).

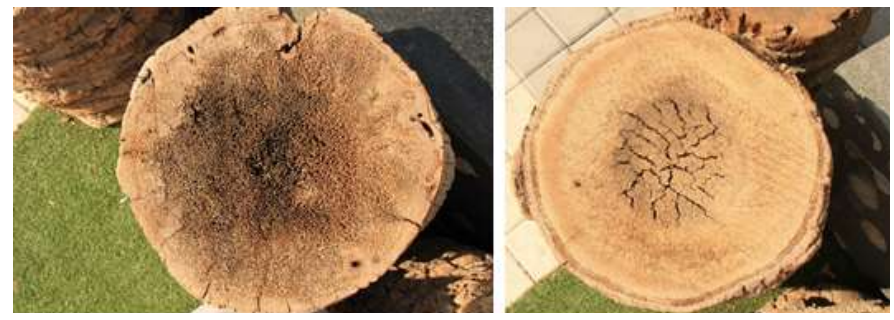

Figure 2: Date palm tree's trunk structure: left almost soft, and right when dried (photos by author)

Using date palms as ornamental and street trees subject to number of aesthetical and beautification specifications such as: slimness and straightness of the palm tree trunk; health conditions; and others. Selection of date palms for such purposes strongly focuses on the characteristics of the palm tree trunks. However, in most cases, date palms have experienced trunks' deformation where they transplanted permanently.

Date palm trees' trunks deformation is noticeable in almost all landscaped areas applying sprinkler irrigation systems. It is also rarely occurred with some other palm species, such as Washingtonia species, along bottom and upper parts as a result of dryness and water stress during transplantation (Broschat 2017). Furthermore, trunk deformity of palm species including Phoenix, Washingtonia, Sabal and others might be linked to the poor rooting immediately after transplantation (Broschat 1991; Costonis 1995; Hodel et al. 2006; Broschat 2017).

This study developed based on a possible hypothesis of linking date palmtrees' trunks deformation to the way of their transplantation, irrigation, and maintenance operations.

The study took place within the cities of the Dammam Metropolitan Area (DMA) (Ad-Dammam, Adh-Dhahran and Al-Khobar). It aimed to define deformation of the date palmtrees' trunks; categorise their types, forms, causes and consequences. Besides developing guidelines for avoiding and reducing deformation rates of the trunks in new landscape projects. 


\section{Materials and Methods}

This study went through three major stages (Figure 3): exploratory study, quantitative qualitative survey, explainatory analysis of the the findings; where several research instruments methods were adopted during each of these stages.

At the initial stage, exploratory methods (mainly direct observation techniques) were used to define the areas of deformation along the date palmtrees'trunks; and to identify its possible causes. A pilot study (operated during the period from November 2016 to April 2017) conducted survey on date palms in different landscaping areas across the DMA. It investigated date palms in streets' medians, soft and hard areas within the parks, waterfronts, plazas, and home gardens. However, the existence of date palms on the selected areas varies from more than 25 years to recently planted. During visits to the selected areas, data of date palms was collected through direct observation and physical measurements. The collected data through pilot study from different areas was analysed and its results were summarized which showed that: deformation along the palm trees' trunks were noticed at bottom, middle, and upper parts. However, majority of date palmtrees' trunks deformations have taken places at the bottom third.

In the second stage, quantitative and qualitative methods were used to investigate frequency and severity of date palm trees' trunks deformations. For this purpose, the Dammam Seafront Corridor was studied in sequential processes include: counting the number of mature and pre-mature date palms, noticing, and recording the deformed parts of the palm trees' trunks. Date palms along the coastal strip of about 17 linear kilometres were investigated one by one during the period from May 2017 until January 2018. More than 1,320 date palms in the case study area were observed for possibility of their trunks' deformation and the causes of such visual appearance.

At the final stage, explanatory study was carried out to interpret the results of analysed data and correlate them to operation and maintenance processes.

Field work for this study was carried on two stages as pilot study to validate the hypothesis and classify the types and locations of date palmtrees' trunk deformation. In the second stage, a case study application on the DCS was deeply searched the causes and consequences of such process and suggesting guidelines to avoid it or reduce their physical and visual implications.

\subsection{Pilot Study}

During the six months (November 2016 to April 2017) of studying samples of date palms in different sites located within the cities of the DMA, direct observations and measurements were applied to define and investigate the forms and levels of date palmtrees' trunk deformation.

Date Palms in nine locations (includes streets' medians and parks) were studied for the purposes

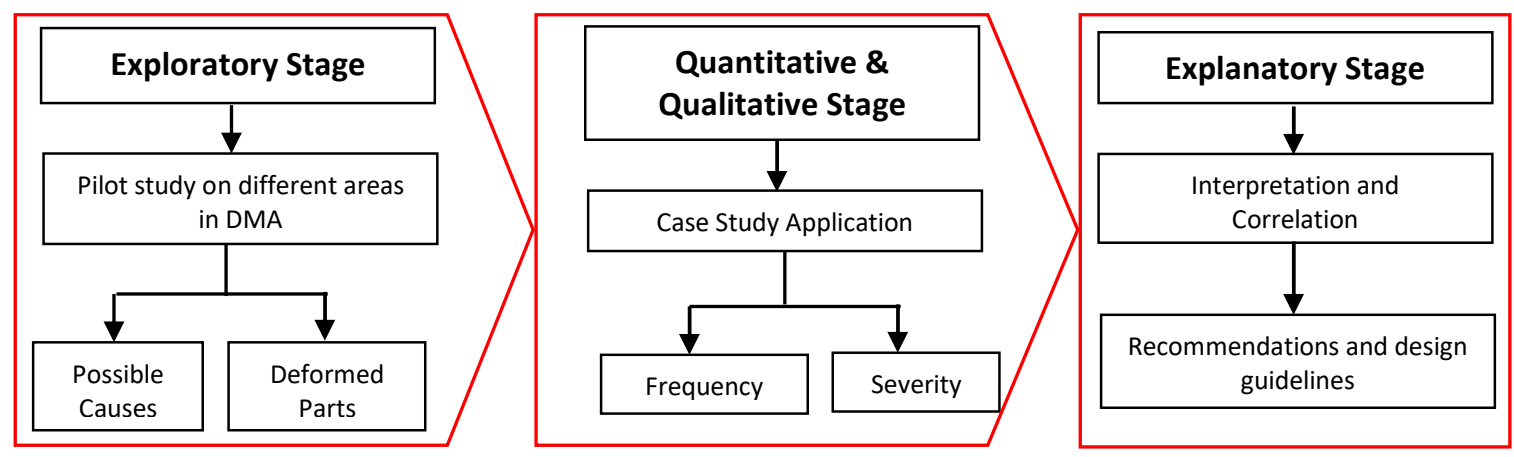

Figure 3: Methodology of investigating date palms trees' trunks deformation went through three stages, each with its own tasks as extended from the previous stage 
of defining the forms, locations and levels of date palm trees' trunks deformation. The locations were selected from the three cities of DMA as follows:

- Prince Turki bin Abdul-Aziz Street in Al-Khobar City

- Prince Faisal Bin Fahd Seafront Park in Al-Khobar

- Northern Al-Khobar cornice

- Al-Agrabiyah Neighbourhood in Al-Khobar City

- Ad-Doha Neighbourhood in Adh-Dhahran City

- Golden Belt neighbourhood in Al-Khobar City

- Ar-Rakah Neighbourhood in Al-Khobar City

- King Abdul-Aziz Street in Ad-Dammam City

- Bin Jelewi Park in Ad-Dammam City

- Ibn Al-Baitar Street in Ad-Dammam City

\subsection{Case Study: The Dammam City Seafront}

For quantitative investigation of severity and frequency of the date palm trees' trunks deformation, the DCS corridor where date palms available was thoroughly surveyed for ten months from May 2017 onward. Along the 17-km coastal park beautified with date palms at different establishment phases (Table 1), more than 1,320 mature and semi-mature date palms were investigated. Investigation process - based on results of the pilot study - divided the palm tree's trunk into three thirds (as they are varying in heights (3-8 meters) according to their ages): bottom, middle and upper. Observations of the palm tree trunk for any possible deformation were recorded based on this division with emphasis on identification of factors that might cause or lead to this effects in each part of the palm tree's trunk.

The Case study area consists of six zones inthree different parts with variations on the ages of date palms (Table 1):

a. the oldest part is the middle including AlMurjan (reef) Island. The date palms in this part are more than 25 years old; b. King Abdullah Seafront Park (KASP) and its adjacent Cornice Road, which is officially opened for public in 2007. Age of date palms in this area is almost 12 years in average; and

c. Seafront of Al-Jawharah Neighbourhood which is the recent part of the whole segment with date palms of three to five years old.

The DCS occupies the southern part of the Tarut Bay and extends between Seahat City at the north and the King Abdulaziz Seaport at the south; whereas the case study area occupies the center of the DCS and forms the area of date palms.

The study employed direct observations of issues including exposure to environmental conditions (such as site characteristics and exposure; and climatic effects (especially wind)), effects of irrigation systems, transplantation, and maintenance process. It also involved certain measurements along the trunk to determine the level,frequency or repetition of deformation on different thirds of the palm trees' trunksin relation to their ages, heights and locations.

Collected data including:

- Total length of clear trunk (in meters)

- Level of deformed bottom third (in meters)

were recorded in spreadsheet file for each date palm tree of 1,321 trees where growth rate (GR) was calculated as division of clear trunk height $(\mathrm{TH})$ (meters) by the age of tree $(A)$ (years):

$$
\mathrm{GR}=\mathrm{TH} / \mathrm{A} \text { (meters per year) }
$$

Also, the expansion (growth) of deformation along the bottom third of 742 affected trees (DG) was calculated as the division of the length of deformed part (LD) (meters) by the total height of the trunk (TH)(in meters) multiplied by growth rate (GR) (meters per year):

$$
\mathrm{DG}=(\mathrm{LD} / \mathrm{TH}) \times \mathrm{GR} \text { (meters per year) }
$$

Statistical Package for Social Sciences (SPSS) software was used to analyze the data and compare the results. 


\section{Results and Discussion}

The results of preliminary field survey enabled the researcher to conclude that:

- Majority of deformed date palm trees' trunks have occurred at bottom third (near the soil surface) which emphasize the hypothesis of irrigation systems contribution in the process of palm trees' trunks deformation. The deformation at this level of the palm tree trunk presents in the forms of blackening bottom part of the palm tree trunk above ground level; enlargement of palm tree trunk base and detachment of the leaves' bases; growth of aerial roots; and appearance of clefts and holes on certain areas of palm trees' trunks (Figure 4).
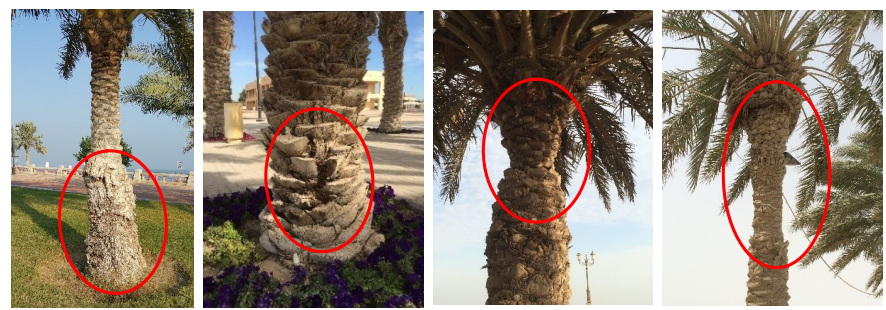

Figure 4: Some forms of deformation along the bottom, middle and upper thirds of the palm trees trunks.

- Deformation takes places on the middle and upper thirds of the palm trees' trunks appears in forms of tapering the palm trees' trunks or reduction of their diameters toward the upper ends (figure 5). Such deformation is thought to be resulting of installation shocks (at earlier stage) and improper maintenance thereafter, that might cause or lead to this effect in each part of the palm tree's trunk.

\subsection{Statistical Analysis}

Analysis of the field data for deformation of date palm trees' trunks revealed the following results (Table 1 and Figure 5):

a. No single palm tree observed with trunk deformation symptoms on the middle third only; usually as combination of all thirds, bottom and middle, or middle and upper. b. $96.9 \%$ (1280 palms) of the total investigated date palms have experienced palm trees' trunks deformation at different levels.

c. $30.4 \%$ (389 Palms) have shown trunk deformation along the trunks on all thirds (bottom, middle and upper).

d. 57.97\% (742 Palms) have suffered trunks deformation along the bottom third of their trunks.

e. The remaining $11.64 \%$ (149 Palms) have suffered trunk deformation along the upper third of their trunks.

f. These figures show that more than $88 \%$ deformed trunks have occurred along the bottom third.

g. The remaining 41 palm trees (3.10\%) with slim elegant trunks are subjected to trunk deformation along bottom, upper thirds or combining both due to malfunction of irrigation systems and maintenance operations.

h. The high percentages of palm tree trunk deformation along the bottom third (More than $75 \%$ in the KASP, $76 \%$ in Al-Hamra waterfront, $57 \%$ in Al-Murjan Island, and $70 \%$ in Al-Jawharah Waterfront) is related to the existence of trees in these areas within the open grass areas. In this case, palm trees are irrigated with bubbler dischargers and get extra moisture on their trunks bottom parts (up to $100 \mathrm{~cm}$ ) from the spray system used for grass irrigation. It is strongly believed that sprinkler nozzles hitting trunks of the date palm trees have great contribution in the deformation of the infected areas. Meanwhile, the low percentage of trunk deformity along bottom third within the trees planted in median and sides of the Cornice Road (18.7\%) is accounted for the absence of sprinkler systems in such landscaped areas.

i. Palm trees of ages exceed 20 years showed low percentages of trunk deformity along upper third. This might be related to the skilled, qualified labours in maintenance of date palms in the past, who are mainly date palms' farmers. 
Table 1: Distribution of the date palm trees in different zones of the Dammam City Seafront (DCS), includes numbers and percentages of trees with deformed trunk in each segment of the $D$

\begin{tabular}{|c|c|c|c|c|c|c|c|}
\hline \multirow{2}{*}{\multicolumn{2}{|c|}{ Segments of the DCS }} & \multirow[b]{2}{*}{$\begin{array}{l}\text { No. of } \\
\text { trees }\end{array}$} & \multirow[b]{2}{*}{$\begin{array}{c}\text { Age } \\
\text { (years } \\
\text { ) }\end{array}$} & \multicolumn{4}{|c|}{ No. of trees with deformed trunk at different levels } \\
\hline & & & & All thirds & $\begin{array}{l}\text { Bottom } \\
\text { third }\end{array}$ & $\begin{array}{l}\text { Upper } \\
\text { third }\end{array}$ & $\begin{array}{c}\text { Total and } \\
\text { percentages of } \\
\text { deformed }\end{array}$ \\
\hline \multirow{2}{*}{\multicolumn{2}{|c|}{$\begin{array}{l}\text { King Abdullah Seafront Park } \\
\text { (KASP) }\end{array}$}} & \multirow{2}{*}{468} & \multirow{2}{*}{12} & 93 & 352 & 19 & 464 \\
\hline & & & & $20.04 \%^{* *}$ & $75.9 \%{ }^{* *}$ & $4.06 \%{ }^{* *}$ & $100 \%$ \\
\hline \multirow{2}{*}{\multicolumn{2}{|c|}{$\begin{array}{l}\text { Cornice Road (as part of } \\
\text { KASP) }\end{array}$}} & \multirow{2}{*}{324} & \multirow{2}{*}{12} & 189 & 59 & 68 & 316 \\
\hline & & & & $59.8 \%{ }^{* *}$ & $18.7 \%^{* *}$ & $21.5 \%{ }^{* *}$ & $100 \%$ \\
\hline \multirow{6}{*}{$\begin{array}{l}\text { Old } \\
\text { Part }\end{array}$} & \multirow{2}{*}{$\begin{array}{l}\text { Al-Hamra Eastern } \\
\text { waterfront }\end{array}$} & \multirow{2}{*}{286} & \multirow{2}{*}{27} & 61 & 204 & 16 & 281 \\
\hline & & & & $21.7 \%^{* *}$ & $76.2 \%{ }^{* *}$ & $2.1 \%{ }^{* *}$ & $100 \%$ \\
\hline & \multirow{2}{*}{$\begin{array}{l}\text { Al-Murjan Island } \\
\text { and its road }\end{array}$} & \multirow{2}{*}{60} & \multirow{2}{*}{20} & 12 & 33 & 13 & 58 \\
\hline & & & & $20.7 \%{ }^{* *}$ & $56.9 \%{ }^{* *}$ & $22.4 \%{ }^{* *}$ & $100 \%$ \\
\hline & \multirow{2}{*}{$\begin{array}{c}\text { Al-Hamra } \\
\text { Northern } \\
\text { Waterfront }\end{array}$} & \multirow{2}{*}{70} & \multirow{2}{*}{27} & 18 & 29 & 21 & 68 \\
\hline & & & & $26.5 \%{ }^{* *}$ & $42.6 \%{ }^{* *}$ & $30.9 \%{ }^{* *}$ & $100 \%$ \\
\hline \multirow{2}{*}{\multicolumn{2}{|c|}{$\begin{array}{l}\text { Al-Jawharah Waterfront (the } \\
\text { recent segment) }\end{array}$}} & \multirow{2}{*}{113} & \multirow{2}{*}{5} & 16 & 65 & 12 & 93 \\
\hline & & & & $17.2 \%{ }^{* *}$ & $69.9 \%{ }^{* *}$ & $12.9 \%{ }^{* *}$ & $100 \%$ \\
\hline & Total & $1,321^{*}$ & & 389 & 742 & 149 & 1,280 \\
\hline \multicolumn{3}{|c|}{ Percentages } & & $30.4 \%^{* * *}$ & $57.97 \%^{* * *}$ & $11.64 \%^{* * *}$ & $96.9 \%^{* * *}$ \\
\hline
\end{tabular}

Source: compiled by author *total includes 41 unaffected trees; ${ }^{* *}$ percentages of trees with deformation along different thirds of the trunk in each segment; and ${ }^{* * *}$ percentages based on the total of trees with deformed trunks in all segments of the DCS $(1,280)$.

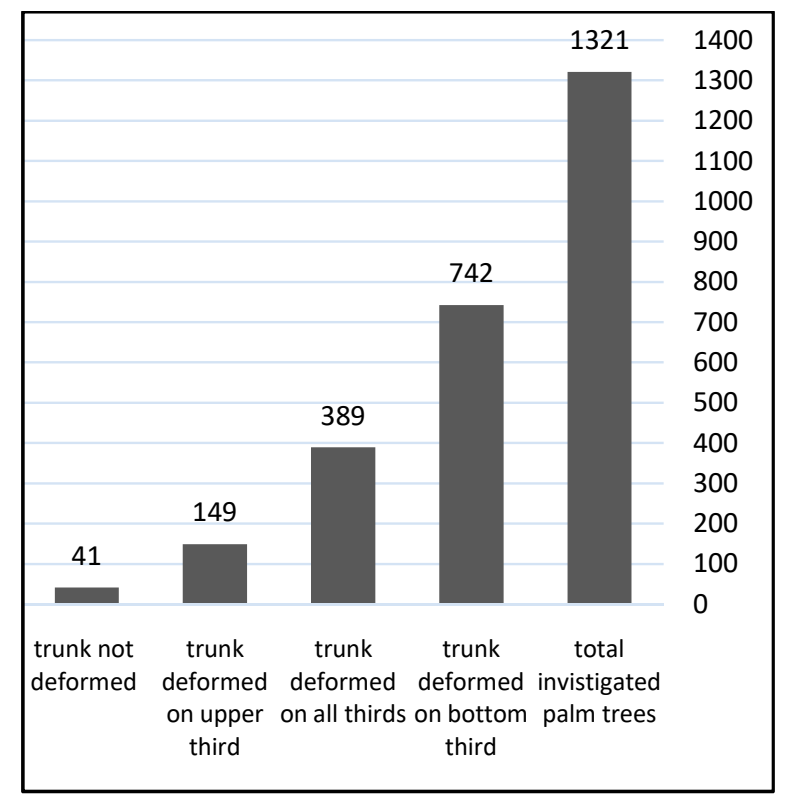

Figure 5: Distribution of palm trees' trunks deformation positions within the study area, where majority occurred along the bottom third of the truck.

Descriptive statistics (Mean (M) and Standard Deviation (SD)) were conducted for the total of 742 date palms with a trunk deformation along the bottom third; and the results are presented in Table 2 below.
The overall means and standard deviations of the trees' trunks deformation expansionratesfor all locations $(M=0.038, S D=0.079)$. Where the maximumdeformation expansion rate was ( $M$ $=0.051, \mathrm{SD}=0.124)$ in Al-Jawharah waterfront, followed by the KASP and Cornice Road ( $M=0.046$ and 0.042 ; and $S D=0.056$ and 0.052 respectively). These results indicate that deformation expansion on the trunks of recently planted palm trees (less than 12 years) are growing at relatively high rate $(0.051$, 0.046 and $0.042 \mathrm{M} / \mathrm{Y}$ ) means they are subjective to increasing deformation along their bottom and upper levels of the trunks.

Table 2: Means and standard deviations of deformation growth according to trees'ages and locations (M/Y).

\begin{tabular}{lccc}
\hline \multicolumn{1}{c}{ Location } & $\begin{array}{c}\text { Number } \\
\text { of trees }\end{array}$ & $\begin{array}{c}\text { Mean (M) } \\
(\mathrm{M} / \mathrm{Y})\end{array}$ & $\begin{array}{c}\text { Std. Deviation } \\
(\mathrm{SD})\end{array}$ \\
\hline KASP & 269 & 0.046 & 0.056 \\
Cornice Road & 183 & 0.042 & 0.052 \\
Al-Hamra East & 163 & 0.027 & 0.030 \\
Al-Murjan & 34 & 0.036 & 0.048 \\
Al-Hamra West & 39 & 0.029 & 0.028 \\
Al-Jawharah & 54 & 0.051 & 0.124 \\
Total (overall) & 742 & 0.038 & 0.079 \\
\hline
\end{tabular}


To ascertain the validity of the differences, the researcher performed the ANOVA one-way analysis, the results presented in Table (3). The results show that there is a statistical significance $(F=294.84$, $\alpha<0.05)$, which interprets differences in the deformation expansion rates between different locations.

Table 3: The results of ANOVA analysis for trunk deformation growth rate of 742 palm trees in all locations.

\begin{tabular}{lcccc}
\hline & $\begin{array}{c}\text { Sum of } \\
\text { Squares }\end{array}$ & $\begin{array}{c}\text { Mean } \\
\text { Square }\end{array}$ & $F$ & $\begin{array}{c}\text { Sig. } \\
(\alpha)\end{array}$ \\
\hline $\begin{array}{l}\text { Between } \\
\text { Groups }\end{array}$ & 4.041 & 0.808 & 249.84 & 0.000 \\
Within & & & & \\
Groups & 4.122 & 0.003 & & \\
Total & 8.163 & 0.811 & & \\
\hline
\end{tabular}

The descriptive statistics ( $M, S D$ ) comparing the types of irrigation dischargers with level of deformation along the bottom third of the palm tree trunks were conducted, and the results are presented in table 4 below.

Table 4: Means and standard deviations of tree irrigation types to palm tree trunk deformation $(M / Y)$

\begin{tabular}{lccc}
\hline $\begin{array}{c}\text { Irrigation } \\
\text { types }\end{array}$ & $\mathrm{N}$ & $\begin{array}{c}\text { Mean (M) } \\
(\mathrm{M} / \mathrm{Y})\end{array}$ & $\begin{array}{c}\text { Std. Deviation } \\
(\mathrm{SD})\end{array}$ \\
\hline Bubbler & 226 & 0.033 & 0.067 \\
Dripper & 430 & 0.022 & 0.085 \\
Sprinkler & 86 & 0.035 & 0.078 \\
Total (overall) & 742 & 0.030 & 0.077 \\
\hline
\end{tabular}

The overall means and standard deviations of the irrigation types for bottom third deformation ( $M=$ $0.030, S D=0.077)$. Where the maximum deformation rate was $(M=0.35, S D=0.078)$ occurred with the sprinkler irrigation system.

To ascertain the validity of types of irrigation systems effects on bottom third deformation, the ANOVA analysis was run, and showed statistical significance ( $F=3.900, \alpha=0.020<0.05$. It can be interpreted as there are effects of different irrigation systems on bottom third of the palm tree trunks (Table 5).
Table 5: The Results of ANOVA for bottom third deformation growth rate

\begin{tabular}{lcccc}
\hline & $\begin{array}{c}\text { Sum of } \\
\text { Squares }\end{array}$ & $\begin{array}{c}\text { Mean } \\
\text { Square }\end{array}$ & $F$ & $\begin{array}{c}\text { Sig. } \\
(\alpha)\end{array}$ \\
\hline $\begin{array}{l}\text { Between } \\
\text { Groups }\end{array}$ & 0.050 & 0.025 & 3.900 & 0.020 \\
$\begin{array}{l}\text { Within } \\
\text { Groups }\end{array}$ & 8.113 & 0.006 & & \\
Total & 8.163 & 0.031 & & \\
\hline
\end{tabular}

Statistical significant differences among types of irrigation system was tested using Post Hoc LSD which revealed the results summarised in table 6 below.

Table 6: Summary of Post Hoc Pairwise Comparisons

\begin{tabular}{|c|c|c|c|c|}
\hline $\begin{array}{c}\text { (I) } \\
\text { Irrigation } \\
\text { type }\end{array}$ & $\begin{array}{l}\text { (J) Irrigation } \\
\text { Type }\end{array}$ & $\begin{array}{c}\text { Mean } \\
\text { Difference } \\
(I-J) \\
\end{array}$ & $\begin{array}{l}\text { Std. } \\
\text { Error }\end{array}$ & Sig. \\
\hline \multirow{2}{*}{ Bubbler } & Dripper & 0.011 & 0.005 & $\begin{array}{c}0.03 \\
8\end{array}$ \\
\hline & Sprinkler & -0.006 & 0.008 & $\begin{array}{c}0.41 \\
5\end{array}$ \\
\hline \multirow{2}{*}{ Dripper } & Bubbler & -0.011 & 0.005 & $\begin{array}{c}0.03 \\
8\end{array}$ \\
\hline & Sprinkler & -0.017 & 0.0070 & $\begin{array}{c}0.02 \\
2\end{array}$ \\
\hline \multirow{2}{*}{ Sprinkler } & Bubbler & 0.006 & 0.008 & $\begin{array}{c}0.41 \\
5\end{array}$ \\
\hline & Dripper & 0.017 & 0.007 & $\begin{array}{c}0.02 \\
2\end{array}$ \\
\hline
\end{tabular}

It is clear from table 6, there is a statistical difference (I-J) between bubbler and dripper irrigation systems where $\mathrm{M}=0.011, \mathrm{SD}=0.005$ and Sig. $=0.038<0.05$. Similarly, there is a statistical difference (I-J) between sprinkler and dripper irrigation systems where $\mathrm{M}=0.017, \mathrm{SD}=0.007$ and Sig. $=0.022<0.05$. And there is no significant differences between sprinkler and bubbler irrigation systems which means both of them has almost similar effects on bottom level trunk deformation.

The above analysis clearly indicate that considerable percentage of palm trees' trunks deformation occur along the bottom third, near ground surface. 
Al-Mana and Ahmed (2010) in their study of date palms trunks' deformity in the street medians of Riyadh city proved that: this phenomenon started from the soil surface up to $120 \mathrm{~cm}$ and they related it to the growth of some fungous species as a result of irrigation systems. Palm tree trunks deformation at this level take the forms of blackening, enlargement or increase of the bases' diameters, detachment of the leaves' bases, growth of aerial roots, and development of clefts and holes. All these symptoms are probably related to transplantation and the way of installing irrigation systems. Transplantation of date palms is a sensitive process to be done by skilfuland experienced labours, from the early stages of digging and lifting the trees from their original ground till the replantation in their permeant locations. Digging palms manually or using mechanical spades require extreme care to protect the roots and retain proper rootballs' sizes. Palms' growth response to their roots cut is crucial (Broschat \& Donselman 1984, 1990) and affected by the size of rootball (Broschat 2017). The rootballs should be $1.5 \times$ the palm tree trunk diameter (0.6 - $0.9 \mathrm{~m}$ diameter), warrped in burlap kept moistened if not immediately planted during transportation (Broschat 2017). Died back roots as a result of cutting, shallow rootball or improper transportation may affect the inner tissues of the plams leading to atorphy of growth point at the top of the palm tree's trunk which appears later as thinner part along the trunk.

Date palms are usually irrigated using drip irrigation system but as they placed on grass areas, they have got sprayed by sprinkler system. The way drip system installed seriously affects the date palm trees' trunks. Bubbler dischargers are commonly used to irrigate palms; and placed $10-30 \mathrm{~cm}$ off palm trees' trunks (Figure 6) with a flow rate up to 2 gallons per minute (GPM). This situation allows continuous bubbling of water on the palm trees' trunks up to $70 \mathrm{~cm}$. above the ground surface, as long as the system running. Al-Mana and Ahmed (2010) concluded that high percentage of deformation associated with the use of bubbler irrigation as water directly and continuously reaching the trunks at different heights.

In addition, sprinkler nozzles (sprayers or rotors) develop very wet media at the bottom level of the palm tree trunks (up to $120 \mathrm{~cm}$ above surface) as they continuously spray the palm tree's trunk or during their back and forth journey in each rotation. Such a wet median between leaves bases become suitable environment for algal and bacterial growth. Al-Mana and Ahmed (2010) have proved the presense of three fungi species in the deformed areas of leaf bases, acting as decomposers facilitating seperation of leaf bases from the trunk. Other studiesobserved that excess moisture encouraged the growth of various fungi species on the deformed areas of leaf bases leading to rot occurrence, decomposition and separation of leaf bases from the trunk (Rashed \& Abdul-Hafeez 2001; El-Meleigi et al. 1993). Also, the high level of humidity that palm tree trunks' fibers hold between leaves bases encourage the growth of aerial roots; especially near the base when the soil is raised to cover bottom parts of the palm trees' trunks.
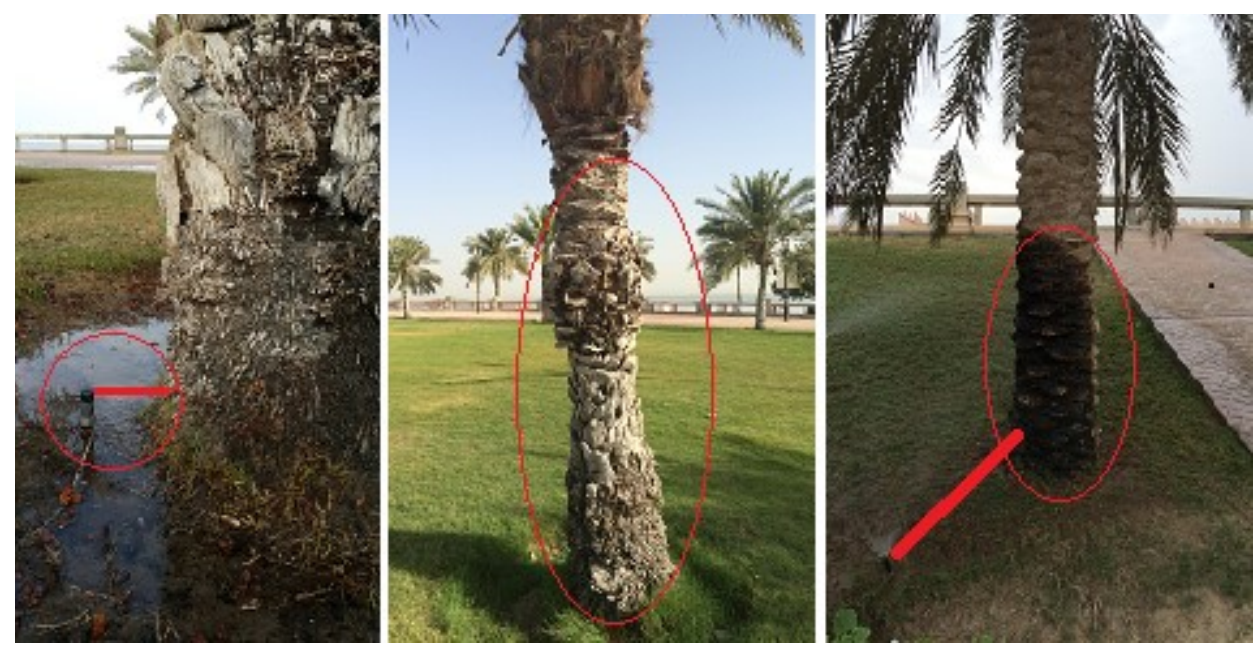

Figure 6: The placement of irrigation dischargers (bubblers $10-30 \mathrm{~cm}$ and closer to the palm tree and sprayers are continuously spraying the trunk) cause serious effects. 
Also, accumulation of excess moisture at the area of leaf bases stimulates the growth of lateral roots leading to separation of the bases and inflation of the trunk in this area (Al-Mana \& Ahmed 2010).

The growth of lateral roots depends on the level of moisture. Maki et al. (1998) explained the process of developing inflated or scraggy trunk near the soil surface. When there is a lack of moisture and lateral roots are unable to get from soil, they die back; and when enough moisture available new lateral roots grow under the dead ones resulting in pushing and separation from the trunk. Repetition of lateral roots growth and death; and separation of leaf bases will lead to scraggy trunk due to corrosion (Al-Mana \& Ahmed 2010). With absence of moisture, the dead roots will bush the leaf bases leading to inflated trunk near the soil surface.

Development of clefts and holes along the bottom third of the palm tree trunk might be a consequence of direct hit of sprayed water on weak parts; usually the places where off-shoots being removed from. As such areas, being continuously hammered by stream of water during irrigation times, external tissues become subject to damages; and this situation help insects and other actors such as fungi and bacteria to widen the clefts and create damage to the internal parts of the palm trees' trunks.

Other forms of palm trees' trunks deformation include tapering and reducing thickness or diameter of the palm trees' trunks which are noticed along the middle and upper thirds of the palm trees' trunks. These forms of deformation are related to transplantation and establishment of the palm trees; and maintenance operations. Transplantation usually passes through several operations include removal from original site, transportation, and replantation. If any improper actions done in any of these stages, post-transplantation shock may affect future growth and cause deformation. Richardson-Calfee and Harris (2005) believed that season of transplantation and its climatic characteristics influences the potential for quick post-transplantation root system regeneration. In case of palm trees, this is crucial as success of palms' transplantation is strongly influenced by wetdry seasonality (Broschat 1998). Care must be taken during digging and transportation of palms.
Moreover, maintenance operations have contributed to the palm trees' trunks deformation at middle and upper thirds. Such deformations are linked to the cutting and removal of the live fronds; and sliming the palm trees' trunks. In most cases, unskilled labours perform maintenance of plant materials in public landscape areas, do the same with the caring of date palms. Date palms have suffered hard cutting of live fronds to the base leading to atrophy or shrinkage of the inner tissues in the areas of the palm trees' trunk immediately below the cut fronds. There is a common practice among date producers and palm trees' farmers that only dry, died fronds to be cut and they never cut any live fronds (Al-Dosary 2016).

Cutting live fronds of the date palms can affect the slimness and regularity of the palm trees' trunk. Osmotic action facilitates and increases bleeding of moisture and nutrients from the surfaces of cut fronds for several days following their removal. This action likely stimulates tissues shrinking at the area of the palm trees' trunks immediately below the cut fronds due to shortages of moisture andnutrients as results of continuous bleeding from the cut surfaces. As palm tree's trunk does not contain cambium layers; and consists of fibrous tissues (Figure 3 ) that can easily shrink and expand based on the nutrients and moisture content.

There is a strong believe that: cutting live fronds, if necessary, must be done $15-20 \mathrm{~cm}$ away from the bases and the cut surfaces must be waxed to prevent or minimize bleeding of nutrients and moisture. In this case, the left $15-20 \mathrm{~cm}$ of petiole (midrib of the leaf) will take enough time to dry back with minimum or no bleeding of nutrients and moisture; and they can be removed to tune up the slimness of the palm trees' trunks during the next maintenance operation or when they became completely dry (AlDosary 2016).

\section{Conclusions}

Using date palm as an ornamental landscaping tree requires extensive care during all stages of uprooting, transportation and transplantation. Majority of 
palm trees' trunks deformation occurred along the bottom third; and it is a function of transplantation and installation of irrigation systems, but other processes include maintenance operation have a share in the trunk deformation appearance.

Thus, it is recommended that extensive care must be taken to follow up the current standards of business during the processes of up-taking tree from its original site, transportation and replantation into the new site. To ensure successful transplantation, a palm tree should be extracted with a rootball of 1.5x the diameter of the trunk, wrapped in burlap tissue immediately after the tree has been lifted; and it should be kept moisturized. During the transportation, the tree must be laid horizontally on the carrier and be sure that rootball is not affected by the load of other trees on top; and it should be moisturized every two hours during transportation in hot seasons.

In the final stage, transplantation in the permanent location should ensure proper layout of irrigation pipes and dischargers; and soil leveling must be kept with the level of the rootball to minimize the chance of developing aerial roots which are the main driving force of expanded and enlarged trunks near the base. Either pipe network of irrigation system neither dischargers should not interfere with the rootball of the tree.Dischargers (drippers or bubblers)should be arranged around the palm trees' trunks at equal distance; and at $50 \mathrm{~cm}$ away from them. Also spraying the palm trees' trunks by sprinkler irrigation system must be avoided or at least its effects should be minimized by planting low shrubs or large ground cover (one meter high) around the palm trees' trunks to diffuse water stream and reduce its direct hitting effects on the palm trees trunks.

Maintenance operations should be scheduled during the mild seasons; insuring proper pruning and avoidance of cutting any live green fronds. It is necessary to be done by professionally trained labors in palm trees' maintenance.

\section{Acknowledgement}

This study has been carried out by the author on his own expenses with support of Eastern
Province Municipality; colleagues of the Landscape Department, Imam Abdulrahman bin Faisal University, Dammam, Saudi Arabia; and Mr. Hasan Al-Dosary. Great Thanks to Dr. Emhaidi Gharaybah and Dr. Ali Bawainah for their help in the statistical analysis of the data.

Conflicts of Interest: The author declares no conflict of interest.

\section{References}

Al-Baker, A. 2002. Date Palms: Past and Present (in Arabic), Second Edition. Beirut: Al-Dar Al-Arabiah for Encyclopedias.

Al-Dosary, H. 2016. Caring date palms. Interview by A. Al-Sulbi. (Date 27.6.2016).

Al-Kashman, O.; Al-Muhtaseb, A. \& Ibrahim, K. 2011. Date Palm (Phoenix dactylifera L.) Leaves as Biomonitors of atmospheric Metal pollution in Arid semi-arid Environments. Environmental Pollution 159, 1635-1640.

Al-Mana, F. \& Ahmed, Y. 2010. Case Study on the Trunk's deformity of Date palms Used in Street Landscape in Riyadh, Saudi arabia. AmericanEurasain Journal of Agricultural and environmental Sciences, Vol. 8, No. 1, 67-72. DOI: 10.17660/ActaHortic.2010.882.41

Al-Shayeb, S.; Al-Rajhi, M. \& Seaward, M.1995. The date palm (Phoenix dactylifera L.) as a bioindicator of lead and other elements in arid environments. Scientific Total Environment 168, 1-10.nDOI: 10.1016/0048-9697(95)04556-G

Al-Wehaibi, M. 2008. Date Palm Biology (in Arabic). King Saud University's Scientific Publishing Centre. Riyadh.

Barreveld, W. 1993. Date Palm Products, Bullet 101. FAO, Agricultural Services. Rome. 
Broschat, T. 2017. Transplanting Palms in the Landscape. Retrieved from IFAS Extension University of Florida. http://edis.ifas.ufl.edu/ ep001 (Date 6.3.2017).

Broschat, T. 1991. Effects of leaf removal on survival of transplanted sabal palms. Journal of Arboriculture 17, 32-33.

Broschat, T. \& Donselman, H. 1990. Regeneration of Severed Roots in Washingtonia robusta Phoenix reclinata. Principes 34, 96-97.

Broschat, T. \& Donselman, H. 1984. Root Regeneration in Transplanted Palms. Principes 28, 90-90.

Broschat, K. 1998. Root Shoot Growth Pattern in Four Palm species their relationship to Air Soil Temperature. Horticulture Science 33, 995-998. DOI:10.21273/HORTSCI.33.6.995

Chao, C. \& Krueger, R. 2007. The date Palms (Phoenix dactylifera L.): Overview of biology, Uses and cultivation. Horticulture Sciences 42, 1077-1082. DOI: 10.21273/HORTSCI.42.5.1077

Costonis, A. 1995. Factors affecting the survival of transplanted sabal palms. Journal of Arboriculture 21, 98-102.

El-Meleigi, M.; Al-Rokibah, A.; Hassan, Z. \& Ibrahim, G. 1993. Vascular wilt of Date Palm (Phoenix dactylifera L.) Caused by Fusarium oxysporum in Al-Gassim Region, Central Saudi arabia. The Third Symposium on the Date Palm in Saudi arabia, Vol. II (pp. 67-76). Al-Hassa, Sudi Arabia: King Faisal University.

FAO 2016. Date Palm Products. Retrieved from Food Agriculture Organization (FAO): www.fao.org/ docrep/t0681e/t0681e01.htm (Date 13.4.2016).

Hodel, D.; Downer, A.; Pittinger, D. \& Beaudoin, P. 2006. Effect of amended backfill soils when planting five species of palm. Horticultural Technology 16, 457-460.
Maki, M.; Hamuda, A. \& Al-Arabi, A. 1998. Pomology of Horticulture: Date Palms, Vol. II (in Arabic). Masqat: New Color Press.

Ministry Of Agriculture (MOA) 2009. The Annual Agricultural Statistical Book, No. 22 (in Arabic). Vice Ministry for Resarch Affairs Agricultural Development, Department of Studies, Planning Statistics. Riyadh.

Moore, H. 1963. An Annotated Checklist of Cultivated Palms. Principles 7, 119-183.

Rashed, M. \& Abdul-Hafeez, N. 2001. Decline of Date Palm Trees in Egypt. Second International Conference on Date Palms, (pp. 401-407). Al-Ain, UAE.

Richardson-Calfee, L. \& Harris, J. 2005. A Review of the Effects of Transplant Timing on Landscape Establishment of Feild-Grown Deciduous trees in temperate Climates. HortTechnology 15 Issue 1, 132-135. DOI: 10.21273/HORTTECH.15.1.0132

Ricks, G. 1992. Landscape Plant Manual for Saudi Arabia. King Abdulaziz University's Scientific Publishing Centre. Jeddah.

Robinson, M. \& Williams, C. 2016. The Date Palm Southern Nevada. Retrieved from University of Nevada: Cooperative Extension: https:// www.unce.unr.edu/publications/files/ho/2002/ sp0212.pdf (Date 21.4.2016).

Sayan, M. 2001. Landscaping with Palms in the Mediterranean. Palms, Vol. 45 No. 4, 171-176.

Simon, H. 1978. The Date Palm: Bread of the Desert. Dodd, Mead \& Company. New York.

Zaid, A. \& de Wet, P. 2016. Date Palm Cultivation - Chapter 1: Botanical systematic Description of Date Palm. Retrieved from FAO Corporate Document Repository: http://www.fao.org/ docrep/006/Y4360E/y4360e05.htm\#bm05.3 (Date 23.4.2016). 